\title{
DWELLING TYPE MATTERS: UNTANGLING THE PARADOX OF INTENSIFICATION AND BICYCLE MODE CHOICE
}

\author{
Trudy Ledsham, Corresponding Author \\ University of Toronto, Geography \& Planning \\ 100 St. George St., Room 5047 \\ Toronto, ON M5S 3G3 \\ Tel: 647-895-0110; Email: trudy.ledsham@utoronto.ca \\ Steven Farber, PhD \\ Assistant Professor \\ Department of Human Geography \\ University of Toronto Scarborough \\ 1265 Military Trail, Toronto, \\ Toronto, ON, M1C1A4 \\ Tel: 416-208-5120; Email: steven.farber@utoronto.ca \\ Nate Wessel \\ University of Toronto, Geography \& Planning \\ 100 St. George St., Room 5047 \\ Toronto, ON M5S 3G3 \\ Tel: 330-936-2849; Email: nate.wessel@mail.utoronto.ca
}

Word count: $6684+3$ tables $\times 250$ words $($ each $)=7,434$ words

Submission Date: July 29, 2016

Revision submitted: November 1, 2016

Publication format submitted: March 6, 2017 


\begin{abstract}
Urban intensification is believed to result in modal shift away from automobiles to more active forms of transportation. This work extends our understanding of bicycle mode choice and the influence of built form, through analysis of dwelling type, density and mode choice. Both apartment dwelling and active transportation are related to intensification, but our understanding of the impact of increased density on bicycling is muddied by lack of isolation of cycling from walking in many studies, and lack of controls for the confounding effects of dwelling type. This paper examines the relationship between dwelling type and mode choice in Toronto. Controlling for 25 variables, this study of 223,232 trips used multinomial logistic regression analysis to estimate relative risk ratios. Compared to driving, we found strong evidence that a trip originating from an apartment-based household was less than half as likely to be taken by bicycle as a similar trip originating in a house-based household in Toronto in 2011. Increased population density of the household location had a positive impact on the likelihood of a trip being taken by walking and a negligible and uncertain impact on the likelihood of it being taken by transit, but a negative impact on bicycling. Further analysis found the negative impact of density does not seem to apply to those living in single detached housing, but rather it only negatively impacts the likeliness of cycling among apartment and townhouse dwellers. Further research is required to identify the exact barriers to cycling, apartment dwellers experience.
\end{abstract}

Keywords: Bicycling, Density, Intensification, Mode Choice, Dwelling, 


\section{INTRODUCTION}

High levels of automobile usage in North American cities result in traffic congestion, air and noise pollution and greenhouse gas emissions, which negatively impact the health and vitality of urban centres. Modal shift away from single occupancy vehicles towards active transportation ( 1 , $2,3)$ is believed to be facilitated by urban intensification, generally achieved through increases in mid and high-rise dwellings and the related increase in population density. However, while intensification contributes to modal shift, it also increases local automotive traffic congestion, as increases in active modes do not occur proportionally to intensification (4, 5). Melia, Parkhurst and Barton (2011) call this the 'Paradox of Intensification' (5). A comprehensive understanding of the reasons for this paradox is not yet available and untangling the factors involved is an important step in finding solutions.

Cycling is particularly well suited to displace some automobile trips in urban areas as the area easily reachable by cycling is more than ten times greater than that by walking (6). It is often faster than either automobile or transit for trips less than $5 \mathrm{~km}$ in length in dense urban areas (7) and offers the same door-to-door convenience as driving. However, the relationship between intensification and cycling is not clear. In Toronto, there are suggestions that residents of mid and high-rise apartment style dwellings bicycle less than residents living in low-rise dwellings. Ipsos Reid (2009) found only 33\% of utilitarian cyclists lived in condominiums apartments or co-ops in comparison to $41 \%$ of the Toronto residents in the survey. $(n=1000$, margin of error $=+/-3.1 \%$ ) (8). The relationship to intensification was not examined. Since approximately $57 \%$ of Toronto households (9) accounting for 47\% (10) of the population, live in mid and high-rise apartment style dwellings, any relationship between dwelling type and mode of transportation is potentially of significant interest to city planners.

We hypothesize that the types of housing typically found in highly intensified neighbourhoods, specifically, mid- and high-rise towers, are less conducive to cycling than lowrise housing resulting in lower cycling mode share among residents. This paper establishes a baseline understanding of the relationship between population density, dwelling type, and travel mode and points to potential areas of research to develop deeper understanding of the influence of dwelling type on cycling.

\section{LITERATURE REVIEW}

Cycling and walking are often lumped together in the mainstream literature on transportation and the built environment $(11,12,13,14,15,16,17,18)$. Krizek, Handy and Forsyth (11) detail important differences between walking and cycling such as trip distance with bicycles covering longer distances at higher speeds; need for bicycles; parking for bicycles; and the policy treatment of bicycles as vehicles, which places them on the roadway with fast moving automobiles, sometime with cycling specific infrastructure, but more frequently without, while walking is assigned its own space on sidewalks. They argue grouping helps analyze nonmotorized travel as it relates to motorized travel, but separation of modes is needed to understand which factors increase or impede walking and cycling.

The literature also does not distinguish between types of housing. Rather, population density and street design (curvilinear versus grid) are mostly used to identify areas with large numbers of single family houses and areas with more mixed, denser housing types $(12,13,14,15,16,17,18)$.

Maximizing non-automotive travel modes is necessary if intensification is to be sustainable and there is extensive research on the relationship between urban form and modal 
choice. In mainstream transportation literature, higher densities, land use diversity and peopleoriented street designs have been associated with higher levels of non-auto transportation, especially within a large body of research focussing on the '3Ds' of the built environment: density, diversity and design (12). 3Ds oriented research has gradually expanded the number of Ds to seven including destination accessibility, distance to transit, demand management and demographics, which are used as controls $(13,15,16,19)$. In the seminal Cervero and Kockleman (12) study, a wide range of variables including population and employment density, diversity of land use mix, design of streets including road patterns, pedestrian and cycling facility provision, and site design features were studied. They found reduced trip rates and more nonauto travel in areas with higher density, greater land-use mix and pedestrian orientation. They did not however include housing type as a variable and all non-automotive travel modes were grouped together.

In similar studies, Kitamura, Mokhtarian and Laidet (14) found that higher levels of residential density, bus accessibility and mixed land uses were associated with a higher share of non-motorized trips but only categorized areas as residential or mixed. Dwelling type was not included in their model and bicycling and walking were combined into non-motorized modes. Dwelling type was not a variable in Cervero's 2002 study of built environments and mode choice that recommended explicit inclusion of land-use variables in mode choice models (16). Additionally, Cervero did not include walking and cycling in his analysis.

Public health oriented reviews found population density a consistent positive correlate of walking and found high walkable neighborhoods had consistently higher levels of walking and cycling than low walkable neighbourhoods but walking and cycling trips were combined $(17,18)$. Ewing and Cervero's 2010 meta-analysis (13) of 50 papers on travel and the built environment found factors strongly related to walking included land use, intersection density, and destinations within walking distance. Their variables did not include dwelling type and bicycling was not a travel option.

Cycling specific research has identified key factors influencing cycling: longer distances reduce the likelihood of cycling $(20,21,22,23)$; higher levels of bicycle infrastructure including parking are positively associated with bicycling $(24,25,26)$; higher levels of bicycle ownership lead to more bicycling $(21,26)$; socio-demographic factors including sex (males cycle more than females), age (older people cycle less) and income (lower incomes equate to higher cycling) influence participation $(23,27,28,29,30)$ as do the social environment and cultural norms of the city $(22,31,32)$. Studies suggest that areas with higher levels of street connectivity, mixed land use and small blocks are more likely to have higher bicycle mode share $(24,33)$.

Higher population density has generally been found to align with higher rates of nonautomotive travel $(1,2,3,12,13,14,15,16,17,18,34)$ but the evidence for cycling alone is less than clear. A study of cycling in Beijing found residential densities had no significant effects on cycling participation. Rather, higher levels of transit services and more main road or expressway crossings were significantly related to less cycling in Beijing (35). Dwelling type was not examined. Cervero and Duncan, examined walking and cycling separately in San Francisco and found mixed evidence on the influence of density (36). Destinations within a 1-mile radius of trip origin encouraged cycling, however within a larger 5-mile radius of a trip origin, higher employment densities discouraged bicycle travel. Cervero et al found density had no relation to cycling in Bogota (37). Winters et al, found population density at the destination was associated with a higher likelihood of cycling (23). Fraser and Lock's systematic review of environment and cycling found only one study where population density was positively associated with 
cycling and that association was weak (38). Zhang found higher population density at trip origin resulted in increased walking, biking and transit for work trips but not for non-work trips, and higher job density at destinations, resulted in increased walking, bicycling and transit (39). Walking and bicycling results were reported together.

The literature on cycling and urban form does not include dwelling type, rather population density is used for analysis. Research frequently combines cycling with other modes particularly walking, but sometime also transit. This study addresses these gaps by using dwelling type and separated modes as factors for analysis. The model produces robust results, despite low cycling mode share, due to the large size of the sample.

\section{STUDY SITE, DATA, AND VARIABLES}

Toronto, located on the north shore of Lake Ontario, has a landmass of $630 \mathrm{~km}^{2}$ and experiences both hot summers and cold winters, although with limited amounts of snow. In 2011, its population was 2.6 million. Density varies from 10,000 people per $\mathrm{km}^{2}$ in the central city, to less than 3,000 people $\mathrm{km}^{2}$ in outer areas (40). However, there are pockets of very high density in the outer areas of the city due to extensive government subsidized high-rise development in the 1960s and 1970s based on the 'tower in the park' housing model. While unusual in North America, this pattern is more common in post-war development in Europe, the former Soviet Union and Asia. Tower development was common throughout the region from the 1960s onwards, as municipalities responded to Metropolitan planning guidelines that prescribed minimum densities for outward growth to support transit and infrastructure such as sewage (41). Condominium development from the 1970s onward was also dispersed throughout the city. As a result, low, mid and high-rise housing is spread throughout the city and is not just a suburban/central city phenomenon. Nor is apartment dwelling always related to income, as there are many, higher-end, mid and high-rise condominiums.

Transportation is oriented towards automobiles, which had a 66\% mode share in 2011. Transit mode share was $26 \%$, while walking was $11 \%$ and bicycling $2 \%$ (42). Most bicycling occurs in the central city wards with cycling mode share as high as $11.25 \%$ while for some wards in the outer areas of the city, it was less than $0.05 \%$ (43). In 2011, cycling specific infrastructure was limited, with no separated bicycle tracks, some painted bike lanes, and a range of recreational trails, mostly unsuited to utilitarian cycling.

Trip data was obtained from the 2011 Transportation Tomorrow Survey (TTS) (42). TTS is a comprehensive travel survey of the Greater Toronto Area (GTA) that has been conducted every five years since 1986 . The study was conducted using landline phones and sampled 5\% of the population over the fall of 2011 and 2012. The data subset used in this study is for the City of Toronto only and consists of 243,375 trips taken by residents of the city. Each of the trips was by a resident who categorized their housing as one of three types: house, apartment or townhouse. The records represent 125,518 persons from 51,961 households (44). Trips are organized by 2006 GTA Traffic Analysis Zone (TAZ) household location. Trips with unknown data values and/or destinations outside of Toronto were eliminated. This resulted in a final data set of 223,232 trips: $34 \%$ of the trips were by residents living in apartments; $7 \%$ were by residents living in townhouses; and 59\% were by residents living in houses.

Weaknesses of the TTS data include the use of landlines, which lead to underreporting by younger residents (aged 18-35) and survey recruitment methods that result in the underreporting of trips by residents of apartment buildings (45). Of the Toronto sample of 243,375 trips, $45 \%$ of the surveys returned were from households living in apartments, however, the 2011 Census 
found 57\% of Toronto households lived in apartments (45). This study does not compensate for these weaknesses although it may be possible in future work to weight the data accordingly. There are differences in how the Census and TTS categorize apartments, with the Census offering more than the three answer options (house, townhouse, apartment) supplied by TTS. An additional weakness of the TTS survey is that mixed mode trips only report the 'main' mode, which is frequently transit, eliminating walk and bicycle segments of the tour, resulting in systemic underreporting of walking and cycling (45). These weaknesses may be important to the results of this study. Overall, TTS data under-represents both cycling and apartment dwellers. However, there is no suggestion that the underrepresentation is skewed towards cyclists from apartment dwellings. We have no reason to think that apartment dwellers who bicycle are less likely to respond to the TTS, than other apartment dwellers. There is also no reason to presume that the young people missing from the survey are especially more likely than other young people to use bicycles and live in apartments. A final weakness may be that the data are clustered, since multiple trips belong to a single individual (at the rate of 1.93 trips per individual) and therefore trips are not independent of each other. In the future, a multi-level model may make our estimates more efficient.

Other variables, that are not TTS related, also have some weaknesses. Income level is an aggregate measure at the TAZ level rather than being related to the individual trip as TTS does not collect income data. The measure of cycling infrastructure is cumulative length within each TAZ and includes recreation oriented trails as well as on street infrastructure. A more robust measure of cycling infrastructure would need to include connectivity, way finding and separation from traffic.

The variables used in our models were calculated using several different data sources and methods that are described in detail in TABLE 1.

\section{METHODOLOGY}

Multinomial logistic regression was used to estimate the impact of each variable on cycling probability using the relative risk ratio (rrr). Relative risk ratios are the exponents of multinomial logit coefficients and are commonly interpreted as odds ratios per unit change (46). Mode type was specified as the dependent variable, with 'drive' as the reference category. Dwelling type was an independent variable. The results show the relative risk ratio of a person choosing transit, bicycle or walk over drive controlling for each variable. Koppelman and Bhat's article on mode choice modelling (47) was used to guide our approach.

\section{RESULTS}

The goodness-of-fit statistics and results of our multinomial logit model appear in TABLE 2. The model has a very high level of fit, as indicated by an extremely significant $\chi^{2}$ test of likelihood ratios and a high pseudo- $R^{2}$.

Each column in TABLE 3 provides the relative risk ratios associated with each mode of transportation, and each row is for a different independent variable. In this model, dwelling type has a very strong influence on whether a person is likely to bicycle. Controlling for all other variables in the model, a trip originating from an apartment-based household was less than half ( $\mathrm{rrr}=0.469, \mathrm{p}<0.001)$ as likely to be taken by bicycle as a similar trip originating in a house-based household in Toronto. People living in townhomes were slightly more likely than apartment 
dwellers to choose bicycle trips, but still significantly less likely than house dwellers to choose bicycle trips ( $\mathrm{rrr}=0.578, \mathrm{p}<0.001)$.

Increased population density of the TAZ was associated with increases in walking compared to driving ( $\mathrm{rrr}=1.08, \mathrm{p}<0.001)$ while the impact on transit use, was insignificant. For bicycling, population density was inversely related $(\mathrm{rrr}=0.785, \mathrm{p}<0.001)$ with high population density of the TAZ of the household location related to less cycling.

To more fully understand the relationship between density and apartment style housing two follow-up analyses were conducted: the effect of dwelling type on the coefficient for density; and the separation of the density effect between single family homes and others. Results showed:

1) The negative impact of density on bicycling is partially moderated by the inclusion of dwelling type in the model. This is evidenced by a change in the density rrr from $(\mathrm{rrr}=0.785, \mathrm{p}<0.001)$ to $(\mathrm{rrr}=0.695, \mathrm{p}<0.001)$ when the model is calibrated with, and without the dwelling type variable.

2) The negative impact of density does not seem to apply to those living in single detached housing, but rather it only seems to negatively impact the likeliness of cycling among apartment and townhouse dwellers. This is seen by the inclusion of an interaction term between density and single detached housing, resulting in an rrr of 0.975 , with no significance for density and an rrr of $0.775, \mathrm{p}<0.001$ for the interaction term.

Results associated with person attributes and cycling were mostly as expected. Women were significantly less likely to bicycle or drive and more likely to walk and take transit than men. However, we did not find that the low cycling participation by apartment residents was due to them being female. These are separate phenomena.

Traffic zone attribute results were less clear. As the distance of household TAZ from the central business increased, the likelihood of cycling compared to driving decreased ( $\mathrm{rrr}=0.712$, $\mathrm{p}<0.001)$ as expected. As the individual median income of the TAZ increased so did the likelihood of walking compared to driving ( $\mathrm{rrr}=1.091, \mathrm{p}<0.001)$. Conversely, the likelihood of bicycling ( $\mathrm{rrr}=0.792, \mathrm{p}<0.001)$ and transit use $(\mathrm{rrr}=0.92, \mathrm{p}<0.001)$ compared to driving declined as the individual median income of the TAZ increased. Higher transit level of service within the TAZ was associated with a slightly higher likelihood of walking and transit trips than driving, and lower likelihoods of cycling trips ( $\mathrm{rrr}=0.785, \mathrm{p}<0.001)$. Both intersection density and destination density had a very small positive effect on the likelihood of cycling. Cycling infrastructure density showed no effect on cycling in this model, although this is likely because of the weaknesses of the measure as described earlier in this paper, particularly the inclusion of recreational trails in the data sets that are difficult to categorize methodically, are not connected to the street network and are often in river valleys with steep egresses.

\section{DISCUSSION AND CONCLUSIONS}

It appears that cycling may not be reaching its full potential in Toronto and many residents are experiencing barriers to cycling related to their housing type. In Toronto, apartment style dwellings shape travel by bicycle almost as much as sex, a widely-acknowledged factor in cycling participation in North America (48). The list of controls in this study is extensive, suggesting that apartment style dwellings, in a manner not yet fully understood, act as a barrier to bicycling.

Dwelling type may act as a proxy for factors that are not generally captured in transportation data. Lack of bicycle parking in apartment buildings in Toronto is an 
acknowledged problem. While no studies specifically identifying shortages of parking at apartment buildings have been conducted in Toronto, a city-wide 2013 study of bicycle parking found $88 \%$ of cyclists and $80 \%$ of non-cyclists agreed with the statement 'There is a shortage of bike parking in the City' (49). The city has passed a by-law requiring indoor bicycle parking for building permits issued from 2016 forward (50). This bylaw does not however, address the very large stock of existing apartments without indoor bicycle parking, and with rules against bicycles in elevators and on balconies. Due to zoning regulations, apartment buildings in Toronto are primarily located on fast moving, wide, multi-lane arterials which generally have no cycling infrastructure and are otherwise considered dangerous to cycle on (51). If a person living in an apartment only travels on large arterials and never sees lower speed, less crowded routes, the possibility of safe cycling to their destinations would seem unlikely. It is also possible that poor health is more common in residents of apartments, with people experiencing health challenges more likely to choose to live in low-maintenance environments. Unfortunately, the TTS does not collect information on health status or the presence of activity limitations. Although this study controlled for income, it was on the aggregate basis of TAZ rather than trip. Lower income of the TAZ was associated with a higher likelihood of cycling, but it may be that below a certain income, the capital costs of a bicycle are prohibitive and prevent acquisition of a bicycle. This very low-income level may be associated with apartment dwelling, but further research would be necessary to understand the relationship.

Smart growth policies have increased population density in Toronto (52). This density is positively associated with the likelihood of walking compared to driving while the relationship to transit is insignificant. However, population density only increases the likelihood bicycling for residents of houses. Residents of houses, generally located on quieter streets, are clearly cycling more as bicycling is increasing rapidly in the city and more and better infrastructure, such as separated cycle tracks is currently being installed, albeit in a limited, tentative manner. In Toronto, no one has successfully identified the reasons for increased cycling, however arguments are made that crowded and expensive transit is a primary driver, alongside a cultural shift. Results of this study showing cycling related to lower levels of transit service ( $\mathrm{rrr}=0.785$, $\mathrm{p}<0.001$ ) support the first part of this theory. Overcrowded transit may mean that transit levels of service do not currently support increases in population density. Overall, this work supports the importance of population density for modal shift and suggests density is not a proxy for housing type and each is a significant variable.

The presence of cycling infrastructure did not show a relationship to increased likelihood of cycling, as areas with very low levels of transport cycling had extensive recreational trail networks with few connections to destinations (43). A few researchers have found similar results in different jurisdictions (33). Nonetheless, most research supports a strong, positive relationship between cycling and infrastructure, when appropriately planned, installed and measured (30, 31, 32).

In future, this model should be refined with a multi-level model to remove the data limitations associated with the clustered trips. Other relevant factors for future research could include dwelling unit density in addition to population density. Square footage of residence, land, and associated storage may also be important factors worth exploring.

Going forward, barriers to cycling for apartment dwellers need to be identified and policies implemented to address the challenges. Further, qualitative research is needed to more fully understand the barriers residents of apartment buildings experience regarding cycling. Smart growth policies may need to be refined, with adjustments such as safe, fully separated 
cycling infrastructure on fast-moving arterial roads, mandated bicycle parking in apartment buildings, and elimination of bans on bicycles in elevators and balconies. These measures may have the potential to significantly increase cycling mode share in Toronto.

The impacts of this study may have relevance for planners elsewhere in the world. For example, the large declines in cycling in many of China's cities have been attributed to changes in the built environment including busier roads and improved transit. However, residential density has no significant effects on the use of bicycles (35). Since much of the population growth in Beijing is associated with high-rise apartments, and destruction of low-rise neighborhoods (53), it is possible that increased apartment housing may also be a contributor to declines in bicycling participation. In our literature review, we found no analysis of transport mode by dwelling type for other cities and it would be useful for future research to examine mode share and dwelling type in other urban areas to confirm the transferability of this research.

As researchers and planners struggle to find the exact combination of influences that contribute to increased active transportation and reduced automobile trips, this research shows that including housing type and separating modes in analyses will contribute to improved understandings. In Toronto, housing type is associated with mode choice. The choice of cycling compared to driving by people living in apartments is less than half as likely when compared to residents in houses, while trips from apartments are more likely to be by transit or walking than driving than similar trips originating from houses.

Multiple measures of urban form, "the D's", are used to estimate the impact on travel including density of population, density of employment, distance to the CBD, diversity of land uses, density of connections, block size, proximity to transit, and destination accessibility. The results of this study suggest that within these parameters, another ' $D$ ' factor-dwelling type-should be considered as an important influence on mode choice. The robustness of this data set and the strong results of this analysis, suggest dwelling type will be a useful area of further inquiry by researchers. Large disaggregated data sets providing the necessary variables are rare, and so this study provides useful evidence for researchers and planners. Future research using a qualitative approach would help improve the understanding of why cycling is lower for residents of apartments.

\section{ACKNOWLEDGEMENTS}

Many thanks to Daniel Arancibia, Michelle Kearns and Dr. Beth Savan.

\section{REFERENCES}

${ }^{1}$ Jabareen, Y. R. Sustainable urban forms their typologies, models, and concepts. Journal of planning education and research, Vol. 26, No. 2, 2006, pp. 38-52.

${ }^{2}$ Litman, T. Land use impacts on transport: How land use factors impact travel

behaviour. Victoria Transport Policy Institute http://www.vtpi.org/landtravel.pdf. Accessed July 23, 2016.

${ }^{3}$ Newman, P. and J. Kenworthy. The ten myths of automobile dependence. World Transport Policy and Practice, Vol. 6, No. 1, 2000, pp. 15-25.

${ }^{4}$ Brownstone, D. Key relationships between the built environment and VMT. Special Report No.298 for the Transportation Research Board, 7. Transportation Research Board of the National Academies, Washington, D.C.,2008. 
${ }^{5}$ Melia, S., G. Parkhurst and H. Barton. The paradox of intensification. Transport Policy, Vol. 18, 2011, pp. 46-52.

${ }^{6}$ Woodcock, J. D. Banister, P. Edwards, A. Prentice and I. Roberts. Energy and transport. The Lancet, Vol. 370, No. 9592, 2007, pp. 1078-88.

${ }^{7}$ Dekoster, J., U. Schollaert and C. Bochu. Cycling: the way ahead for towns and cities. Office for Official Publications of the European Communities, 2000.

${ }^{8}$ Ipsos Reid City of Toronto Cycling Study Tracking Report 1999 and 2009.December 1, 2010. http://nacto.org/wp-content/uploads/2010/08/City-of-Toronto-Cycling-Study-Tracking-Report1999-and-2009.pdf. Accessed July 23, 2016.

${ }^{9}$ City of Toronto Community Council Profiles (2011).

http://www1.toronto.ca/City\%20Of\%20Toronto/City\%20Planning/Wards/Files/pdf/C/CCA_STE \%20Census\%20Profile\%202011.pdf. Accessed October 24, 2016.

${ }^{10}$ Statistics Canada. (2011). Census of Canada: Topic base tabulations: Structural Type of Dwelling (10), Age Groups (21) and Sex (3) for the Population in Occupied Private Dwellings of Canada, Provinces, Territories, Census Divisions and Census Subdivisions.

https://www12.statcan.gc.ca/census-recensement/2011/dp-pd/tbt-tt/Rpeng.cfm?LANG $=$ E \&APATH $=5 \& D E T A I L=0 \& D I M=0 \& F L=A \& F R E E=0 \& G C=3520005 \& G I D=$ $0 \& \mathrm{GK}=3 \& \mathrm{GRP}=0 \& \mathrm{PID}=103685 \& \mathrm{PRID}=0 \& \mathrm{PTYPE}=101955 \& \mathrm{~S}=0 \& \mathrm{SHOWALL}=0 \& \mathrm{SUB}=0 \&$ Temporal=2011\&THEME=91\&VID=0\&VNAMEE=\&VNAMEF=. Accessed October 24, 2016.

${ }^{11}$ Krizek, K. J., S.L. Handy, and A. Forsyth. Explaining changes in walking and bicycling behavior: challenges for transportation research. Environment and Planning B: Planning and Design, Vol. 36, No. 4, 2009, pp. 725-740.

${ }^{12}$ Cervero, R and K. Kockelman. Travel demand and the 3Ds. Transportation Research D, Vol. 2, No. 3, 1997, pp. 199-219.

${ }^{13}$ Ewing, R., and R. Cervero. Travel and the built environment: a meta-analysis. Journal of the American planning association, Vol.76, No. 3, 2010, pp. 265-294.

${ }^{14}$ Kitamura, R. P. L. Mokhtarian, and L. Laidet. A micro-analysis of land use and travel in five neighborhoods in the San Francisco Bay Area. Transportation Vol. 24, No. 2, 1997, pp.125-158. ${ }^{15}$ Ewing, R., and R. Cervero. Travel and the built environment: a meta-analysis. Journal of the American planning association, Vol. 76, No. 3, 2010, pp. 265-294.

${ }^{16}$ Cervero, R. Built environments and mode choice: toward a normative framework.

Transportation Research Part D: Transport and Environment, Vol.7, No. 4, 2002, pp. 265-284.

${ }^{17}$ Saelens, B. E., J.F. Sallis, and L.D. Frank. Environmental correlates of walking and cycling: findings from the transportation, urban design, and planning literatures. Annals of behavioral medicine, Vol.25, No. 2, 2003, pp. 80-91.

${ }^{18}$ Sallis, J. F., L.D. Frank, B.E. Saelens, and M. K. Kraft. Active transportation and physical activity: opportunities for collaboration on transportation and public health research.

Transportation Research Part A: Policy and Practice, Vol. 38, No. 4, 2004, pp. 249-268.

${ }^{19}$ Ewing, R., et al. "Measuring the impact of urban form and transit access on mixed use site trip generation rates-Portland pilot study'." US Environmental Protection Agency, Washington, DC (2009).

${ }^{20}$ Handy, S. L., and Y. Xing. Factors correlated with bicycle commuting: a study in six small US cities. International Journal of Sustainable Transportation, Vol. 5, No. 2, 2011, pp. 91-110. 
${ }^{21}$ Buehler, R. Determinants of bicycle commuting in the Washington, DC region: The role of bicycle parking, cyclist showers, and free car parking at work. Transportation research part D: transport and environment, Vol.17, No. 7, 2012, pp. 525-531.

${ }^{22}$ Heinen, E., K. Maat, and B.Van Wee. The role of attitudes toward characteristics of bicycle commuting on the choice to cycle to work over various distances. Transportation research part D: transport and environment, Vol.16, No.2, 2011, pp. 102-109.

${ }^{23}$ Winters, M., M. Brauer, E.M. Setton and K. Teschke. Built environment influences on healthy transportation choices: bicycling versus driving. Journal of urban health, Vol. 87, No. 6, 2010, pp. 969-993.

${ }^{24}$ Buehler, R. and J. Pucher. Cycling to work in 90 large American cities: new evidence on the role of bike paths and lanes. Transportation, Vol. 39, No. 2, 2012, pp. 409-432.

${ }^{25}$ Dill, J. and T. Carr. Bicycle commuting and facilities in major US cities: if you build them, commuters will use them. Transportation Research Record: Journal of the Transportation Research Board, (1828) Transportation Research Board of the National Academies, Washington, D.C., 2003. pp. 116-123.

${ }^{26}$ Moudon, A. V., C. Lee, A.D. Cheadle, C.W. Collier, D. Johnson, T. L. Schmid, and R.D. Weather. Cycling and the built environment, a US perspective. Transportation Research Part D: Transport and Environment, Vol. 10, No. 3, 2005, pp. 245-261.

${ }^{27}$ Krizek, K. J., P.J. Johnson, and N. Tilahun. Gender differences in bicycling behavior and facility preferences. Research on Women's Issues in Transportation, Vol. 2, 2005, pp. 31-40. ${ }^{28}$ Garrard, J., G. Rose and S.K. Lo. Promoting transportation cycling for women: the role of bicycle infrastructure. Preventive medicine, Vol. 46, No. 1, 2008, pp. 55-59.

${ }^{29}$ Winters, M., M.C. Friesen, M. Koehoorn and K. Teschke. Utilitarian bicycling: a multilevel analysis of climate and personal influences. American journal of preventive medicine, Vol. 32, No. 1, 2007, pp. 52-58.

${ }^{30}$ Emond, C., W. Tang, and S. Handy. Explaining gender difference in bicycling behavior. Transportation Research Record: Journal of the Transportation Research Board, No. 2125, Transportation Research Board of the National Academies, Washington, D.C., 2009, pp.16-25.

${ }^{31}$ Pucher, J. and R. Buehler. City Cycling. MIT Press, Cambridge, MA. 2012.

${ }^{32}$ Handy, S., B. Van Wee and M. Kroesen. Promoting cycling for transport: research needs and challenges. Transport reviews, Vol. 34, No. 1, 2014, pp. 4-24.

${ }^{33}$ Dill, J. and K. Voros. Factors affecting bicycling demand: initial survey findings from the Portland, Oregon, region. Transportation Research Record: Journal of the Transportation Research Board, No. 2031, Transportation Research Board of the National Academies, Washington, D.C., 2007, pp. 9-17.

${ }^{34}$ Chen, C., H. Gong and R. Paaswell. Role of the built environment on mode choice decisions: additional evidence on the impact of density. Transportation, Vol. 35, No. 3, 2008, pp.285-299.

${ }^{35}$ Zhao, P. The impact of the built environment on bicycle commuting: Evidence from Beijing. Urban studies Vol. 51, No. 5, 2014, pp. 1019-1037.

${ }^{36}$ Cervero, R., and M. Duncan. Walking, bicycling, and urban landscapes: evidence from the San Francisco Bay Area. American journal of public health, Vol. 93, No. 9, 2003, pp. 1478-1483. 
${ }^{37}$ Cervero, R., O. Sarmiento, E. Jacoby, L F. Gomez and A. Neiman Influences of built environments on walking and cycling: lessons from Bogotá. International Journal of Sustainable Transportation Vol. 3, No. 4, 2009, pp.203-226.

${ }^{38}$ Fraser, S. D. and K. Lock Cycling for transport and public health: a systematic review of the effect of the environment on cycling. The European Journal of Public Health, Vol. 21, No. 6, 2011, pp. 738-743.

${ }^{39}$ Zhang, M. The role of land use in travel mode choice: Evidence from Boston and Hong Kong. Journal of the American planning association, Vol. 70, No. 3, 2004, pp. 344-360.

${ }^{40}$ City of Toronto. Ward Profiles 2011.

http://www1.toronto.ca/wps/portal/contentonly?vgnextoid=fee133a114b10410VgnVCM100000 71d60f89RCRD Accessed June 9, 2015.

${ }^{41}$ E.R.A. Architects (2010). Tower Renewal in the Greater Golden Horseshoe: An Analysis of High-Rise Apartment Tower Neighbourhoods Developed in the Post-War Boom (1945-1984). http://cugr.ca/pdf/TNR_GGH.pdf. Accessed October 24, 2016.

42 Data Management Group, University of Toronto Civil Engineering (DMG). (2016). Transportation Tomorrow Survey.

${ }^{43}$ Ledsham, T. G. Liu, E. Watt, K. Wittmann. Mapping Cycling Behaviour in Toronto. Toronto Cycling Think \& Do Tank, University of Toronto. 2013..

http://www.torontocycling.org/uploads/1/3/1/3/13138411/mapping_cycling_behaviour_in_toront o_final_23_may_printer_tl.pdf Accessed July 16, 2016.

${ }^{4 \overline{4}}$ Data Management Group University of Toronto Civil Engineering. Transportation Tomorrow 2011 TTS Version 1.0 Data Guide. http://dmg.utoronto.ca/pdf/tts/2011/dataguide2011.pdf Accessed July 16, 2016.

${ }^{45}$ Data Management Group University of Toronto Civil Engineering. Transportation Tomorrow Survey, 2011, Data Expansion and Validation Version 1.0 2013.

http://dmg.utoronto.ca/pdf/tts/2011/validation2011.pdf Accessed April 12, 2016.

${ }^{46}$ Stata Annotated Output Multinomial Logistic Regressions. UCLA: Statistical Consulting Group. From http://www.ats.ucla.edu/stat/stata/output/stata_mlogit_output.htm. Accessed April 8, 2016.

${ }^{47}$ Koppelman, F. S. and C. Bhat. A self-instructing course in mode choice modeling: multinomial and nested logit models. US Department of Transportation, Federal Transit Administration 31, 2006.

${ }^{48}$ Emond, C., W. Tang and S. Handy. Explaining gender difference in bicycling behavior. Transportation Research Record: Journal of the Transportation Research Board, No. 2125, Transportation Research Board of the National Academies, Washington, D.C 2009, pp. $16-25$.

${ }^{49}$ City of Toronto. Transportation Services, Bicycle Parking Study: Key findings report. 2015. http://www1.toronto.ca/City\%20Of\%20Toronto/Transportation\%20Services/Cycling/Files/pdf/P /Bicycle\%20Parking\%20Study\%20-\%20Full\%20Report.pdf Accessed July 19, 2016.

${ }^{50}$ City of Toronto Zoning By-law 569-2013. Chapter 230 Bicycle Parking Space Regulations. http://www.toronto.ca/zoning/bylaw_amendments/ZBL_NewProvision_Chapter230_20.htm. Accessed July 12, 2016.

${ }^{51}$ Bassil, K., H. Rilkoff, M. Belmont, A. Banaszewska, and M. Campbell. Toronto Public Health. Pedestrian and Cyclist Safety in Toronto. 
http://www.toronto.ca/legdocs/mmis/2015/h1/bgrd/backgroundfile-81601.pdf. Accessed July 23, 2016.

52 Statistics Canada. Focus on Geography Series, 2011 Census, Census subdivision of Toronto, C-Ontario. https://www12.statcan.gc.ca/census-recensement/2011/as-sa/fogs-spg/Facts-csdeng.cfm?Lang=eng\&GK=CSD\&GC=3520005 Accessed July 11, 2016.

${ }^{53}$ Shin, H. B. Residential redevelopment and social impacts in Beijing in China's emerging cities: The making of new urbanism, Edited by F. Wu, Routledge, Abingdon, 2007, pp. 163-184.

\section{LIST OF TABLES}

TABLE 1 Data Sources, Variable Descriptions and Transformations

TABLE 2 Results and Model Fit

TABLE 3 Results Relative Risk of Bicycle, Walk, Transit Modes Compared to Drive 


\section{TABLE 1 Data Sources, Variable Descriptions and Transformations}

\begin{tabular}{|c|c|c|c|}
\hline Variable & Source & Original Data Description & $\begin{array}{l}\text { Reclassified and Transformed Data } \\
\text { Description }\end{array}$ \\
\hline $\begin{array}{l}\text { Primary } \\
\text { mode of } \\
\text { travel }\end{array}$ & TTS & $\begin{array}{l}\text { Public Transit (excluding GO } \\
\text { Rail), Bicycle, Auto Driver, } \\
\text { GO Rail, } \\
\text { Joint GO Rail and Public } \\
\text { Transit, Motorcycle, Other, } \\
\text { Auto Passenger, } \\
\text { School Bus, Taxi, Walk, } \\
\text { Unknown }\end{array}$ & $\begin{array}{l}\text { Reduced to: } \\
\text { Transit - (GO, Joint, Public Transit, } \\
\text { School bus), } \\
\text { Drive - (including driver, passenger, } \\
\text { motorcycle, taxi), } \\
\text { Bicycle } \\
\text { Walk } \\
\text { Other and Unknown were dropped }\end{array}$ \\
\hline $\begin{array}{l}\text { Type of } \\
\text { dwelling }\end{array}$ & TTS & $\begin{array}{l}\text { House, Apartment, } \\
\text { Townhouse, Unknown }\end{array}$ & $\begin{array}{l}\text { House, Apartment, Townhouse, } \\
\text { Unknown was dropped }\end{array}$ \\
\hline $\begin{array}{l}\text { Population } \\
\text { density }\end{array}$ & TTS & $\begin{array}{l}\text { Population of TAZ } \\
\text { Area of TAZ }\end{array}$ & $\begin{array}{l}\text { People per square kilometer, in tens } \\
\text { of thousands }\end{array}$ \\
\hline Sex & TTS & Male, Female, Unknown & $\begin{array}{l}\text { Male, Female, Unknown was } \\
\text { dropped }\end{array}$ \\
\hline Age & TTS & Ages 11 to 99 & unchanged \\
\hline Age squared & TTS & Ages 11 to 99 & Age squared \\
\hline $\begin{array}{l}\text { Apartment } \\
\& \text { female }\end{array}$ & TTS & $\begin{array}{l}\text { Female Boolean variable } \\
\text { Apartment Boolean Variable }\end{array}$ & $\begin{array}{l}\text { Female and apartment }=1 \\
\text { Otherwise } 0\end{array}$ \\
\hline $\begin{array}{l}\text { Employment } \\
\text { status }\end{array}$ & TTS & $\begin{array}{l}\text { Full time, Work at home full } \\
\text { time, Work at home part time, } \\
\text { Not employed, Part time, } \\
\text { Unknown }\end{array}$ & $\begin{array}{l}\text { Reduced to: Full Time - (full time, } \\
\text { work at home fulltime), Part time - } \\
\text { (part time, work at home part time), } \\
\text { Not employed, } \\
\text { Unknown was dropped }\end{array}$ \\
\hline Occupation & TTS & $\begin{array}{l}\text { General Office \& Clerical, } \\
\text { Manufacturing \& Construction } \\
\text { \&Trades, Professional } \\
\text { \&Management \&Technical, } \\
\text { Retail Sales and Service, Not } \\
\text { Employed, Unknown }\end{array}$ & Unknown was dropped \\
\hline $\begin{array}{l}\text { Student } \\
\text { status }\end{array}$ & TTS & $\begin{array}{l}\text { Not a student, Part time } \\
\text { student, Full time student } \\
\text { Unknown }\end{array}$ & $\begin{array}{l}\text { Reduced to: Student, Not student, } \\
\text { Unknown was dropped }\end{array}$ \\
\hline $\begin{array}{l}\text { Driver's } \\
\text { license }\end{array}$ & TTS & $\begin{array}{l}\text { Does trip taker have a driver's } \\
\text { license? Yes, No, Unknown }\end{array}$ & Yes, No Unknown was dropped \\
\hline Transit pass & TTS & $\begin{array}{l}\text { Combination or Dual Pass, } \\
\text { GO Transit Pass, Metro Pass, }\end{array}$ & $\begin{array}{l}\text { Reduced to: No Pass (None), Pass } \\
\text { (Combination GO, Metro Pass, Other }\end{array}$ \\
\hline
\end{tabular}




\begin{tabular}{|c|c|c|c|}
\hline & & $\begin{array}{l}\text { None, Other Agency Pass, } \\
\text { Unknown }\end{array}$ & $\begin{array}{l}\text { Agency Pass), Unknown was } \\
\text { dropped }\end{array}$ \\
\hline $\begin{array}{l}\text { Number of } \\
\text { persons in } \\
\text { household }\end{array}$ & TTS & & \\
\hline $\begin{array}{l}\text { Vehicle } \\
\text { Ownership } \\
\text { per person }\end{array}$ & TTS & $\begin{array}{l}\text { \# of vehicles in household } \\
\text { /\# of persons in household }\end{array}$ & Vehicles per person \\
\hline $\begin{array}{l}\text { Individual } \\
\text { median } \\
\text { income of } \\
\text { TAZ }\end{array}$ & $\begin{array}{l}\text { Statistics Canada } \\
\text { National } \\
\text { Household Survey } \\
2011 \text {, census } \\
\text { tracts }\end{array}$ & $\begin{array}{l}\text { Individual median income per } \\
\text { census tract }\end{array}$ & $\begin{array}{l}\text { Apportioned to origin TAZs from } \\
\text { census tracts using area } * \text { density } \\
\text { weights }\end{array}$ \\
\hline $\begin{array}{l}\text { Transit level } \\
\text { of service }\end{array}$ & $\begin{array}{l}\text { GTFS, } \\
\text { DMTI CanMap } \\
\text { Postal Code Suite, } \\
\text { DMTI Route } \\
\text { Logists Street } \\
\text { Network File }\end{array}$ & $\begin{array}{l}\text { \# of distinct transit trips } \\
\text { accessible within } 400 \mathrm{~m} \text { walk } \\
\text { of a postal code centroid, in a } \\
\text { 24-hour period }\end{array}$ & $\begin{array}{l}\text { Average taken across postal code } \\
\text { centroids inside origin TAZs, number } \\
\text { of transit trips in thousands }\end{array}$ \\
\hline $\begin{array}{l}\text { Intersection } \\
\text { density }\end{array}$ & $\begin{array}{l}\text { DMTI CanMap } \\
\text { Route Logistics }\end{array}$ & $\begin{array}{l}\text { Locations of three- and four- } \\
\text { way intersections }\end{array}$ & $\begin{array}{l}\text { Number of three- and four-way } \\
\text { intersections per square kilometer, in } \\
\text { tens. }\end{array}$ \\
\hline $\begin{array}{l}\text { Bicycle } \\
\text { infrastructur } \\
\text { e density }\end{array}$ & $\begin{array}{l}\text { City of Toronto } \\
\text { Open Data } \\
\text { v_centrelines_od_- } \\
\text { bikeways_april } \\
2012\end{array}$ & $\begin{array}{l}\text { Cycling infrastructure } \\
\text { polylines } \\
\text { Area of TAZ }\end{array}$ & $\begin{array}{l}\text { Meters of cycling infrastructure per } \\
\text { square kilometer, in origin TAZ } \\
\text { divided by } 100\end{array}$ \\
\hline $\mathrm{Km}$. to $\mathrm{CBD}$ & TAZ geometries & TAZ geometry file & $\begin{array}{l}\text { Euclidean distance }(\mathrm{km}) \text { from the } \\
\text { centroid of the household location } \\
\text { TAZ to the corner of King St. W. and } \\
\text { Bay St. downtown. }\end{array}$ \\
\hline $\begin{array}{l}\mathrm{Km} . \text { to } \mathrm{CBD} \\
\text { squared }\end{array}$ & TAZ geometries & TAZ geometry file & Distance squared \\
\hline $\begin{array}{l}\text { Destination } \\
\text { density at } \\
\text { trip } \\
\text { destination }\end{array}$ & $\begin{array}{l}\text { DMTI Spatial, } \\
\text { "Enhanced Points } \\
\text { of Interest" }\end{array}$ & $\begin{array}{l}\text { Enhanced points of interest } \\
\text { classified by Standard } \\
\text { Industrial Classification }\end{array}$ & $\begin{array}{l}\text { Number of Points of interest per } \\
\text { square kilometer, within the TAZ of } \\
\text { the destination }\end{array}$ \\
\hline $\begin{array}{l}\text { Household } \\
\text { location } \\
\text { destination } \\
\text { density }\end{array}$ & $\begin{array}{l}\text { DMTI Spatial, } \\
\text { "Enhanced Points } \\
\text { of Interest" }\end{array}$ & $\begin{array}{l}\text { Points of interest classified by } \\
\text { Standard Industrial } \\
\text { Classification }\end{array}$ & $\begin{array}{l}\text { Number of Points of interest per } \\
\text { square kilometer, within the TAZ of } \\
\text { the household }\end{array}$ \\
\hline Trip distance & TTS & $\begin{array}{l}\text { Manhattan trip distance in } \\
\text { meters }\end{array}$ & Converted to $\mathrm{km}$. \\
\hline $\begin{array}{l}\text { Trip distance } \\
\text { squared }\end{array}$ & TTS & $\begin{array}{l}\text { Manhattan Trip distance in } \\
\text { meters }\end{array}$ & Converted to $\mathrm{km}$. Distance squared \\
\hline Trip purpose & TTS & $\begin{array}{l}\text { Home-based work (i.e. home- } \\
\text { to-work or work-to-home), } \\
\text { Home-based-school, Home- } \\
\text { based-discretionary, Non- } \\
\text { Home-based (i.e. neither end } \\
\text { is home) }\end{array}$ & unchanged \\
\hline
\end{tabular}


TABLE 2 Results and Model Fit

Description

Number of observations

223,232

LR chi2 (87)

184182.02

Prob $>$ chi2

0.0000

Pseudo R2

.4712

Log likelihood

$-103343.02$ 
TABLE 3 Results Relative Risk of Bicycle, Walk, Transit Modes Compared to Drive

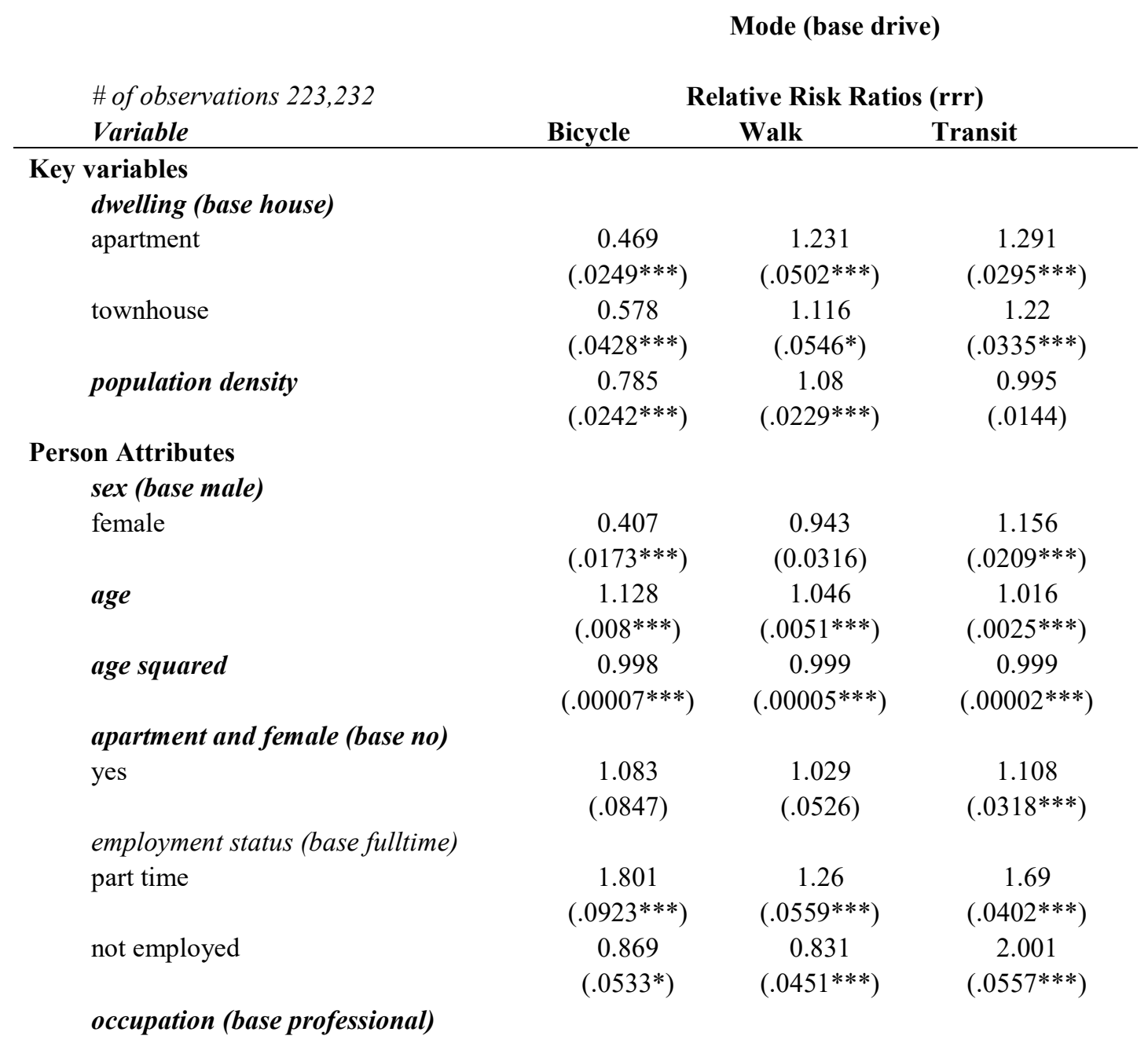




\begin{tabular}{|c|c|c|c|}
\hline general office/clerical & $\begin{array}{c}0.78 \\
(.0481 * * *)\end{array}$ & $\begin{array}{c}1.089 \\
(0.0547)\end{array}$ & $\begin{array}{c}1.199 \\
\left(.0305^{* * *}\right)\end{array}$ \\
\hline manufacturing/construction & $\begin{array}{c}0.518 \\
(.0413 * * *)\end{array}$ & $\begin{array}{c}0.345 \\
(.0300 * * *)\end{array}$ & $\begin{array}{c}0.448 \\
\left(.0165^{* * *}\right)\end{array}$ \\
\hline retail & $\begin{array}{c}0.635 \\
(.0299 * * *)\end{array}$ & $\begin{array}{c}0.72 \\
\left(0.298^{* * *}\right)\end{array}$ & $\begin{array}{c}0.863 \\
\left(.0187^{* * *}\right)\end{array}$ \\
\hline \multicolumn{4}{|l|}{ student status (base student) } \\
\hline not a student & $\begin{array}{c}0.689 \\
\left(.0530^{* * *}\right)\end{array}$ & $\begin{array}{c}0.537 \\
(.0324 * * *)\end{array}$ & $\begin{array}{c}1.057 \\
(.0344)\end{array}$ \\
\hline \multicolumn{4}{|l|}{ driver's license (base yes) } \\
\hline no & $\begin{array}{c}2.426 \\
(.1182 * * *)\end{array}$ & $\begin{array}{c}3.451 \\
(.1262 * * *)\end{array}$ & $\begin{array}{c}3.31 \\
\left(.0634^{* * *}\right)\end{array}$ \\
\hline \multicolumn{4}{|l|}{ transit pass (base no) } \\
\hline yes & $\begin{array}{c}1.016 \\
(0.0622)\end{array}$ & $\begin{array}{c}2.947 \\
\left(.1156^{* * *}\right)\end{array}$ & $\begin{array}{c}11.93 \\
(.2137 * * *)\end{array}$ \\
\hline \multicolumn{4}{|l|}{ Household Attributes } \\
\hline persons in household & $\begin{array}{c}0.584 \\
\left(.0093^{* * *}\right)\end{array}$ & $\begin{array}{c}0.723 \\
\left(.0078^{* * *}\right)\end{array}$ & $\begin{array}{c}0.742 \\
\left(.0046^{* * *}\right)\end{array}$ \\
\hline vehicles per person & $\begin{array}{c}0.078 \\
\left(.0049^{* * *}\right)\end{array}$ & $\begin{array}{c}0.136 \\
\left(.0067^{* * *}\right)\end{array}$ & $\begin{array}{c}0.103 \\
\left(.0028^{* * *}\right)\end{array}$ \\
\hline \multicolumn{4}{|l|}{ Traffic Zone Attributes } \\
\hline individual median income & $\begin{array}{c}0.792 \\
\left(.0140^{* * *}\right)\end{array}$ & $\begin{array}{c}1.091 \\
\left(.0149^{* * *}\right)\end{array}$ & $\begin{array}{c}0.92 \\
\left(.0073^{* * *}\right)\end{array}$ \\
\hline transit level of service & $\begin{array}{c}0.785 \\
(.0472 * * *)\end{array}$ & $\begin{array}{c}1.079 \\
\left(.0311^{* *}\right)\end{array}$ & $\begin{array}{c}1.031 \\
(.0157 *)\end{array}$ \\
\hline intersection density & $\begin{array}{c}1.026 \\
(.0043 * * *)\end{array}$ & $\begin{array}{c}1.013 \\
(.0037 * * *)\end{array}$ & $\begin{array}{c}0.999 \\
(.0022)\end{array}$ \\
\hline bicycle infrastructure density & $\begin{array}{c}0.99 \\
\left(.0017^{* * *}\right)\end{array}$ & $\begin{array}{c}0.998 \\
(0.0014)\end{array}$ & $\begin{array}{l}1.001 \\
(.0008)\end{array}$ \\
\hline km to $C B D$ & $\begin{array}{c}0.712 \\
\left(.0128^{* * *}\right)\end{array}$ & $\begin{array}{c}0.834 \\
(.0097 * * *)\end{array}$ & $\begin{array}{c}0.911 \\
\left(.0060^{* * *}\right)\end{array}$ \\
\hline$k m$ to $C B D$ squared & $\begin{array}{c}1.006 \\
(.0007 * * *)\end{array}$ & $\begin{array}{c}1.005 \\
\left(.0004^{* * *}\right)\end{array}$ & $\begin{array}{c}1.002 \\
(.0002 * * *)\end{array}$ \\
\hline $\begin{array}{l}\text { destination density within the } T A Z \text { of } \\
\text { the trip destination }\end{array}$ & $\begin{array}{c}1.024 \\
\left(.0016^{* * *}\right)\end{array}$ & $\begin{array}{c}1.043 \\
(.0014 * * *)\end{array}$ & $\begin{array}{c}1.04 \\
(.0007 * * *)\end{array}$ \\
\hline destination density in household $T A Z$ & $\begin{array}{c}0.994 \\
(.0014 * * *)\end{array}$ & $\begin{array}{l}0.998 \\
\left(.0006^{*}\right)\end{array}$ & $\begin{array}{c}0.999 \\
\left(.0006^{* * *}\right)\end{array}$ \\
\hline \multicolumn{4}{|l|}{ Trip Attributes } \\
\hline trip distance & $\begin{array}{c}0.832 \\
\left(.0046^{* * *}\right)\end{array}$ & $\begin{array}{c}0.243 \\
\left(.0034^{* * *}\right)\end{array}$ & $\begin{array}{c}1.02 \\
\left(.0009^{* * *}\right)\end{array}$ \\
\hline trip distance squared & $\begin{array}{c}1.0003 \\
\left(.00001^{* * *}\right)\end{array}$ & $\begin{array}{c}1.002 \\
\left(.00004^{* * *}\right)\end{array}$ & $\begin{array}{c}0.9999 \\
\left(6.68 \mathrm{e}-06^{* * *}\right)\end{array}$ \\
\hline \multicolumn{4}{|l|}{ trip purpose (base work) } \\
\hline home to school & $\begin{array}{c}1.395 \\
\left(.1356^{* * *}\right)\end{array}$ & $\begin{array}{c}1.522 \\
\left(.0949^{* * *}\right)\end{array}$ & $\begin{array}{c}1.78 \\
(.0643 * * *)\end{array}$ \\
\hline home to discretionary & 0.234 & 0.0375 & 0.167 \\
\hline
\end{tabular}




\begin{tabular}{cccc} 
& $\left(.0105^{* * *}\right)$ & $\left(.0015^{* * *}\right)$ & $\left(.0036^{* * *}\right)$ \\
non home-based & 0.268 & 0.0599 & 0.163 \\
& $\left(.0145^{* * *}\right)$ & $\left(.0028^{* * *}\right)$ & $\left(.0042^{* * *}\right)$ \\
\hline
\end{tabular}

standard error in ( )

$* * *$ Significant at the $p<.001$ level

$* *$ Significant at the $p<.01$ level

* Significant at the $p<.05$ level 